NASA/TM-1998-208660

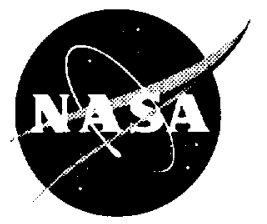

\title{
The Evaluation of a Modified Chrome Oxide Based High Temperature Solid Lubricant Coating for Foil Gas Bearings
}

Chris DellaCorte

Lewis Research Center, Cleveland, Ohio

Prepared for the

Annual Meeting

sponsored by the Society of Tribologists and Lubrication Engineers

Las Vegas, Nevada, May 23-27, 1999

National Aeronautics and

Space Administration

Lewis Research Center 
Trade names or manufacturers' names are used in this report for identification only. This usage does nut constitute an official endorsement, either expressed or implied, by the National Aeronautics and Space Adr inistration.

This report is a preprint of a paper intended for presentation at a conference. Because of changes that may be made before formal put lication, this preprint is made available with the understanding that it will not $b \in$ cited or reproduced without the permission of the aut ior.

Available from

NASA Center for Aerospace Information

7121 Standard Drive

Hanover, MD 21076

Price Code: A03
National Technical Information Service 5285 Port Royal Road Springfield, VA 22100

Price Code: A03 


\title{
THE EVALUATION OF A MODIFIED CHROME OXIDE BASED HIGH TEMPERATURE SOLID LUBRICANT COATING FOR FOIL GAS BEARINGS
}

\author{
Chris DellaCorte \\ National Aeronautics and Space Administration \\ Lewis Research Center \\ Cleveland. Ohio 44135
}

\begin{abstract}
This paper describes the friction and wear performance of PS304, a modified chrome oxide based coating, for foil gas bearings. PS304 contains $60 \mathrm{wt} \% \mathrm{NiCr}$ binder, $20 \mathrm{wt} \% \mathrm{Cr}_{2} \mathrm{O}_{3}$ hardener. and 10 wt $\%$ each $\mathrm{Ag}$ and $\mathrm{BaF}_{2} /$ $\mathrm{CaF}_{2}$ lubricants. For evaluation, the coating is plasma spray deposited onto test journals which are slid against a superalloy partial arc foil bearing. The test load was $10 \mathrm{KPa}(1.5 \mathrm{psi})$ and the bearings were run under start/stop cyclic conditions. The data show good wear performance of the bearing especially at temperatures above $25^{\circ} \mathrm{C}$. Bearing friction was moderate $(\mu \cong 0.4)$ over the entire temperature range. Based upon the results obtained. the PS304 coating has promise for high temperature, oil-free turbomachinery applications.
\end{abstract}

Key words: Gas Bearings, Solid Lubricants. High Temperature

\section{INTRODUCTION}

Significant advances in the performance of Compliant Surface Foil Gas Bearings have renewed interest in their application in high temperature, high speed Oil-free Turbomachinery (refs. I and 2). These self-acting, hydrodynamic air-bearings offer much technological potential due to their low friction. and high speed, high temperature capabilities. During normal operation the bearings float on a self generating air film and experience no wear. Wear protection during start-up and shut-down, however remains a technical obstacle especially for Iong-life. high temperature operation (refs. 3 and 4). Recent research on PS300, a chrome oxide based solid lubricant coating, has shown promise for foil gas bearings (ref. 5).

PS300 is a plasma sprayed, $\mathrm{NiCr}$ bonded, chrome oxide based coating with $\mathrm{Ag}$ and $\mathrm{BaF}_{2} / \mathrm{CaF}_{2}$ lubricant additions. It has shown good friction and wear properties in pin-on-disk testing from 25 to $650{ }^{\circ} \mathrm{C}$. For foil bearings PS300 is applied to the journal (shaft) by plasma spraying followed by grinding prior to testing. In a recent paper. PS300 was successful in lubricating a foil gas bearing at $500{ }^{\circ} \mathrm{C}$ for over 15,000 start-stop cycles (ref. 5). Al $25^{\circ} \mathrm{C}$. 
however, friction and foil wear were excessive. Furthermore, repeated thermal cycling above $500{ }^{\circ} \mathrm{C}$ resulted in spalling of the coating (delamination) from the journal surface. This 'ailure mechanism was attributed to a mismatch in thermal expansion coefficients (CTE's) between the coating and the substrate (ref. 5). Follow-on research identified a new coating composition. designated PS304, which contains the same constituents as PS.304 but altered ratios of binder to chrome oxide. PS304 has nearly the same CTE as typical superalloy substrates $\left(14 \times 10^{-6} / \mathrm{C}\right)$ and exhibits good friction and wear properties in pin-on-disk testing to $800^{\circ} \mathrm{C}$ (ref. 6).

The present work, reported in this paper, evaluates PS304 in a partial-arc foil gas bearing from 25 to $650{ }^{\circ} \mathrm{C}$. Results are compared to PS300 bearing tests and pin-on-disk testing for PS300 and PS304.

\title{
EXPERIMENTAL MATERIALS
}

\author{
Test Specimens
}

The PS 304 coating is evaluated using a partial-arc foil bearing test rig shown in figure one and described in detail in reference 7 . The specimens are a foil bearing and a coated shaft or journal. The bearing consists of a corrugated bump foil and a smooth top foil made from a precipitation hardened $\mathrm{NiCr}$ alloy. Inconel X-750, 0.10 mm thick. The bare foil specimens are tested against superalloy shafts coated with a $0.25 \mathrm{~mm}$ thick layer of PS304. Figure 2 shows, schematically, the test specimens. The PS304 coatings are applied by plasma spraying to a thickness of $0.30 \mathrm{~mm}$ followed by finish grinding to a diameter of $38 \mathrm{~mm}$ and a surface finish $100.2 \mu \mathrm{m} \mathrm{rms}$.

The PS304 coating contains $60 \mathrm{wt} \% \mathrm{NiCr}, 20 \mathrm{wt} \% \mathrm{Cr}_{2} \mathrm{O}_{3}$ and $11 \mathrm{wt} \%$ each of $\mathrm{Ag}$ and $\mathrm{BaF}_{2} / \mathrm{CaF}_{2}$ eutectic. The $\mathrm{NiCr}$ acts as a binder. The $\mathrm{Cr}_{2} \mathrm{O}_{3}$ acts as a hardening additive and as a high temperature lubricant. The silver and fluoride additions are low and high temperature lubricants respectively. Figure 3 shows a cross-section photomicrograph of a PS304 coating. The measured coefficient of thermal exparsion is about $12.4 \times 10^{-6} / \mathrm{C}$ which closely matches the superalloy substrates of $14 \times 10^{-6} / \mathrm{C}$. Reference 8 describ $s$ the coating and deposition process in more detail.

\section{TEST PROCEDURE}

The specimens are tested in a high temperature foil bearing test 1 ig under repeated start/stop cycling. Each cycle lasts $20 \mathrm{sec}$ consisting of a $1.3 \mathrm{sec}$ period in which the spindle drive notor is on, followed by a $7 \mathrm{sec}$ period in which the drive motor is shut off. During the first few seconds of the on per od the spindle accelerates to full speed 
$(13,800 \mathrm{rpm})$ and then runs at this speed for about $10 \mathrm{sec}$ prior to motor shut-down. The bearing develops a hydrodynamic lubricating air film at speeds above about $4000 \mathrm{rpm}$. Following motor shut-down, the spindle coasts to a stop in about $5 \mathrm{sec}$. Sliding between the foil and the coated shaft occurs when the spindle speed drops below $4000 \mathrm{rpm}$. Bearing friction (torque) is measured continuously during the test cycle with a calibrated load cell connected to a torque arm which prevents bearing rotation. Bearing friction is then estimated by dividing the measured torque by the total bearing weight and the torque arm length. A chart recorder is used to monitor and record the torque and spindle speed data. A once-per-cycle counter keeps track of elapsed cycles. A typical friction-speed trace is shown in figure 4 . The test sequence lasts for 30.000 cycles. Bearing wear was measured every 10,000 cycles by interrupting the tests and using a vernier micrometer to measure journal diameter changes (coating wear) and bearing foil thickness (foil wear). The test load was $10 \mathrm{kPa}(1.5 \mathrm{psi})$ and is chosen to simulate a typical near term turbomachin-ery application. Test temperatures ranged from 25 to $650^{\circ} \mathrm{C}$ and were achieved using quartz tube radiant heaters shown in figure 1. Reference 7 describes the test rig and procedures in more detail. Following testing, journal wear was more completely/accurately measured using stylus profilometry. Selected wear surfaces were examined with SEM/EDS to elucidate the wear process.

\section{RESULTS AND DISCUSSION}

The tribological data is comprised of foil wear, journal wear and bearing friction. Foil wear is expressed by measuring the reduction in foil thickness at the most worn area of the foil. This area is typically in the foil center since it supports the bulk of the deadweight load. The foil is considered "worn out" or no longer usable when 25 percent of the original foil thicknesses, $0.025 \mathrm{~mm}$ for these foils, is removed. Bearing performance can be degraded if wear beyond this point occurs in a heavily loaded application. Foil wear is measured using a micrometer with a ball tip.

Journal wear is also measured with a micrometer and checked for accuracy after testing is completed with a stylus profilometer. Journal wear is considered excessive if more than $0.025 \mathrm{~mm}$ is worn from the diameter. Wear beyond this point results in a significant increase in the bearing clearance and can affect bearing performance and stability especially under low loads and high speeds. Bearing friction (Torque) is presented as a friction coefficient calculated from torque measurements conducted during normal start/stop operation.

It was observed early in this test program that the bearing torque was significantly decreased by relatively small temperature increases especially at low ambient temperatures, e.g. 25 versus $200^{\circ} \mathrm{C}$. Upon closer examination of the data, it became apparent that this thermal affect was due to a reduction in preload of the foil against the journal. All 
foil bearings are initially sized with a small spring loading or interference with the shaft to ensure bearing stability especially under light loads. Thus the measured torque is due to both the preload or wrapping force of the foil against the journal as well as the friction contribution from the applied load (weight).

To separate the friction due to the preload from that due to the applied load. torque measurements were made under several test loads. These were then plotted against the total load and a least squares fit was applied to the data. The slope from this fit is taken as the calculated friction coefficient for the test conditions considered. Figure 5 shows this calculation graphically. By making this calculation it may be possible to compare friction from the particular bearing to results previously obtained with the pin-on-disk rig

The tribological data is summarized in table I and shown graphically in figures 6 to 8 . Data uncertainties shown represent scatter from repeated measurements made at roughly 5,000 cycle intervals and from at least 2 repeat tests of different specimens under identical test conditions. The data is characterized by a marked decrease in wear at test temperatures higher than $25^{\circ} \mathrm{C}$ and uniform friction coefficients over the entire temperature range. Both foil and journal wear were 5 to 10 times higher at $25^{\circ} \mathrm{C}$ than at $650^{\circ} \mathrm{C}$ as shown in table I and figures 7 and 8 .

At $25^{\circ} \mathrm{C}$. the foils experienced at 25 percent thickness reduction of $0.0025 \mathrm{~cm}$ after only $15,000 \mathrm{star} / \mathrm{stops}$. Several tests were continued beyond this pre-established wear limit. The foil wear continued in an approximately linear fashion reaching $0.0046 \mathrm{~cm}$ after 30.000 cycles. The foil wear decreased drastically to about 5 percent $\Leftrightarrow(0.0005 \mathrm{~cm})$ of the foil thickness after 30,000 cycles at all temperatı res above $25^{\circ} \mathrm{C}$.

Journal wear mirrored the foil wear behavior. At $25^{\circ} \mathrm{C}$ the diametral journal wear was $0.0025 \mathrm{~cm}$ reaching the established wear limit after 30,000 cycles. At elevated temperatures, the wear ranged from 0.0004 to $0.0009 \mathrm{~cm}$. The reasons for the tribological behavior observed may be elucidated by examining the results of the wear surface analyses. Table II summarizes the findings of EDS X-RAY analyses :onducted on foil and journal surfaces after completing $30,0 \%)$ start/stop cycles.

At $25^{\circ} \mathrm{C}$ the foil wear rate is high and no detectable transfer fronı the PS304 coating occurs. Some Fe is detected on the worn journal perhaps coming from foil wear debris. The lack of any detectable lubricant (Ag, $\mathrm{Ca}, \mathrm{Ba})$ transfer from the coating to the foil explains the high wear observed. At $204^{\circ} \mathrm{C}$, no lubricants but significant $\mathrm{Fe}$ and $O$ is detected on the journal surface. Other than the appearance of an ' )xygen peak. no changes to the foil surface chemistry were observed. See figure 9. Considering the dramatic rede ction in foil and journal wear, compared to $25^{\circ} \mathrm{C}$. it is plausible that a lubricious iron oxide $\left(\mathrm{Fe}_{3} \mathrm{O}_{4}\right)$ has formed (n the journal surface. Certain oxides of iron have been shown to be good solid lubricants under certain sliding conditions (refs. 9 and 10).

In contrast. after testing $427^{\circ} \mathrm{C}$ the coatings intrinsic lubricants ( Ag, Ca, Ba), not Fe oxide, appear to providing a significant lubrication role. Although detectable on the journal surfece, the observed Fe peak is small compared to the Ag, Ca and Be peaks. See figure 10. The foil surface clearly show; the presence of oxygen but not transferred 
lubricants. In this case, the low friction and wear observed could be the result of both in-situ formed lubricious oxides and chrome oxides and lubricants found in the coating.

Bearings run at $538^{\circ} \mathrm{C}$ experience detectable lubricant transfer from the journal coatings to the foil surface. See figure 11. The journal surface contains all of the coatings original constituents and exhibits an apparent rise in both $\mathrm{Cr}$ and Si peak heights compared to Ni. This observation may suggest the formation of a chromium silicate compound. Although not a major coating constituent, silicon is present in the coating in the form of an anticaking agent added to the $\mathrm{NiCr}$ binder powder by the manufacturer at concentration around $1 \mathrm{vol} \%$. Independent trials at the author's lab using NiCr binder without this additive indicate that its presence has no measurable affect on the tribological properties of the coating. Nonetheless the simultaneous rise in the Si and Cr peaks in the EDS spectrum suggest an interaction. Whatever the case, tribological performance is not hindered.

After operation at $650{ }^{\circ} \mathrm{C}$, foil surfaces show continued transfer of lubricants (Ag. Ca. Ba) from the journal as well as a clear oxygen peak. The journal surface contains all of the original constituent plus small Fe and Mo peaks (from the foil). Although the Ti peak in the spectra interferes with the Ba peak. the presence of Ca is coupled with Ba since the $\mathrm{BaF}_{2} / \mathrm{CaF}_{2}$ eutectic in the coating is prefused. Thus, if a peak is observed at the $\mathrm{Ba} / \mathrm{Ti}$ location $\approx 4.5 \mathrm{KeV}$ ) without a $\mathrm{Ca}$ peak than the peak at $\approx 4.5 \mathrm{KeV}$ is probably $\mathrm{Ti}$. However when the $\mathrm{Ca}$ peak is present the peak at $\approx 4.5 \mathrm{KeV}$ is resulting from $\mathrm{Ba}$ alone or $\mathrm{Ba}$ and titanium.

These surface analyses clearly show that there are compositional differences among the surfaces generated at varying temperatures. Despite these variations, bearings tested at elevated temperatures exhibit a common character. They all show reduced friction and wear compared to the room temperature case, which experienced high wear and no significant surface composition changes. Clearly, lubricant transfer and surface film formation has a positive effect on lowering friction and wear.

This behavior corroborates earlier work with the PS304 coating and similar coating systems (refs. 6 and 11 ). Pin-on-disk testing showed that good tribological properties occurred in conjunction with lubricant surface film formation and transfer to the sliding counterface. Of course, the absence of heneficial transfer at room temperature may be simply the consequence of an increased wear rate of the foil resulting in the wearing away of any transferred lubricants. The development of solid lubricants which can provide superior performance (i.e., comparable to MoS or graphite) at low temperatures while being capable of surviving high temperature use remains an as yet unmet challenge (ref. 12).

Similar temperature/wear performance characteristics were observed in both partial-arc bearing and pin-on-disk (table III) tests of PS300 which differed from PS304 in its ratio of binder to $\mathrm{Cr}_{2} \mathrm{O}_{3}$. In those tests, wear was also higher at room temperature. However, the wear at $25^{\circ} \mathrm{C}$ was so severe that the bearings wore through after only 3000 cycles (ref. 5). Clearly, compositional changes alone can reduce the room temperature wear but more changes 
need to be made to enhance performance. Fortunately, the intended applications for foil bearings (turbochargers, auxiliary power units and gas turbines) experience most of their operition at elevated temperatures. Room temperature wear, in these cases, are not an issue.

\section{CONCLUDING REMARKS}

The tribological performance of PS304 in partial-arc foil bearings was evaluated. From the friction and wear data it is ohserved that friction is, more or less, independent of the test temperature while wear is markedly higher at room temperature than at elevated temperatures. Post-test surface analyses suggest that reduced wear results when surface enrichment and transfer of lubricants occurs. Although the specific surface composition and apparent lubrication mechanism differs for each elevated test temperature, the wear performance is quite uniform. Based upon these results, these coatings show great promise for high temperature foil bearings in Oil-free Turbomachinery applications.

\section{REFERENCES}

1. Heshmat, H.: Advancements in the Performance of Aerodynamic Foil Journal Bearings: High Speed and Load Capability," ASME Tribology Conference. Paper No. 93-Trib-32. 1993.

2. Heshmat. H. and Ku. C.P.R: "Structural Damping of Self-Actin : Compliant Foil Bearings," ASME Tribology Conference, Paper No. 93-Trib-16, 1993.

3. Chen, S.H. and Arora, G.K., "Development of a $1000^{\circ} \mathrm{F}, 10,000$ Star/Stop cycle foil Journal Bearing for a Gas Turbine Engine," AIAA Paper No. A87-23253. Proceedings of 22 $2^{\text {nd }}$ Joint Propulsion Conference. Huntsville, Alabama, June 16-18. 1986, No. 86-1457.

4. Bushan, B. and Rusietto. D.: "Hydrodynamic Air Lubricated Ccmpliant Surface Bearing for an Automotive Gas Turbine Engine-II Materials and Coatings," NASA CR-1 35402, July 1978.

5. DellaCorte. C.: Fellenstein, J.A. and Benoy, P.A: "Evaluation of a Chrome Oxide Based and Chrome Carbide Based Solid Lubricants Coating for Foil Gas Bearings at 25 and $500{ }^{\circ} \mathrm{C}$. NASA TM-206619. 1998.

6. DellaCorte, C. and Fellenstein, J.A.: "The Effect of Compositional Tailoring of the Thermal Expansion and Tribological Properties of PS300: A Solid Lubricant Compos te Coating," Tribology Transacations, Vol. 40. 1997. pp. 639-642.

7. Dellacorte. C.: "Composition Optimization of Chromium Carbi te Based Solid Lubricant Coatings for Foil Gas Bearings at Temperatures to $650^{\circ} \mathrm{C}, "$ NASA CR-179649, July 1987. 
8. DellaCorte, C. and Edmonds, B.J.: "Preliminary Evaluation of PS300: A New Self-Lubricating High Temperature Composite Coating for Use to $800^{\circ} \mathrm{C} . "$ NASA TM-107056, (1995).

9. Bowden. F.P. and Tabor, D.: "The Friction and Lubrication of Solids" Clarendon Oxford Press. Oxford UK. 1986, pp. 290-292.

10. Ludema, K.C. and Donnson, A.: "Mechanics and Chemistry in Lubrication," Esevier Press, Amsterdam. 1985. pp. 18.3-185.

11. DellaCorte, C. and Sliney, H.E.: "Composition Optimization of Self-Lubricating Chromium Carbide Based Composite Coatings for Use to $760^{\circ} \mathrm{C}$. ASLE Transactions, Vol. 30. No. 1. pp. 77-83 (1987).

12. Sliney. H.E., "Some Composite Bearing and Seal Materials for Gas Turbine Applications-A Review," J. of Eng. For Gas Turhines and Power. Transactions of ASME. Vol. 112, pp. 486-491. 1990.

TABLE I.-FRICTION AND WEAR SUMMARY: [Test conditions: 30,000 start/stop cycles. 10.2 kPa load]

\begin{tabular}{|c|c|c|c|}
\hline $\begin{array}{l}\text { Test temperature. } \\
{ }^{\circ} \mathrm{C}\end{array}$ & $\begin{array}{c}\text { Calculated friction } \\
\text { coefficient }\end{array}$ & $\begin{array}{c}\text { Foil wear, } \\
\mathrm{cm}\end{array}$ & $\begin{array}{l}\text { Journal coating } \\
\text { diametral wear. } \\
\text { cnl }\end{array}$ \\
\hline 25 & $0.40 \pm 0.04$ & $\because 0.0046 \pm 0.001$ & $0.0025 \pm 0.0005$ \\
\hline 204 & $0.39 \pm 0.05$ & $0.0005 \pm 0.0001$ & $0.0005 \pm 0.0002$ \\
\hline 426 & $0.39 \pm 0.02$ & $0.0 \times 003 \pm 0.0(0) 1$ & $0.0 \times(24 \pm 0.0 \times 0) 2$ \\
\hline 5.38 & $0.40 \pm 0.03$ & $0.000(44 \pm 0.0002$ & $0.0 \times 099 \pm 0.0004$ \\
\hline 650 & $0.33 \pm 0.03$ & $0.0005 \pm 0.0002$ & $0.000 .5 \pm 0.0002$ \\
\hline
\end{tabular}

"Data uncertainies represent scatter between repeat tests. At least two repeats performed for each test temperature.

"Friction coefficient calculated as slope of bearing torque versus applied load plot measured at 10,000 cycle intervals from 5 to $30 \mathrm{kPa}$ static loads.

'Testing continued beyond $0.0025 \mathrm{~cm} 125$ percent foil thickness) wear limit.

TABLE II-EDS-X-RAY ANALYSIS SUMMARY OF WORN FOIL AND JOURNAL SURFACES

\begin{tabular}{|c|c|c|c|}
\hline \multirow{2}{*}{$\begin{array}{c}\text { Test condition/test } \\
\text { temperature }\end{array}$} & \multicolumn{2}{|c|}{ Major elements present } & \multirow{2}{*}{ Remarks } \\
\hline & Foil surface & Journal surface & \\
\hline Pretest/unworn & $\mathrm{Ni} . \mathrm{Cr}, \mathrm{Fe}, \mathrm{Ti}, \mathrm{Mo}$ & Ni. Cr, O, Ag. Ba, Ca. trace $\mathrm{Si}$ & Constituents detected \\
\hline $\begin{array}{l}25^{\circ} \mathrm{C} \\
75^{\circ} \mathrm{F}\end{array}$ & Ni, Cr, Fe, Ti, Mo & $\mathrm{Ni}, \mathrm{Cr}, \mathrm{O}, \mathrm{Ag} . \mathrm{Ca}, \mathrm{Ba} . \mathrm{He} . \mathrm{Si}$ & $\begin{array}{l}\text { Fe transfer from foil to journal } \\
\text { No journal coating transfer to foil }\end{array}$ \\
\hline $\begin{array}{l}204^{\circ} \mathrm{C} \\
4000^{\circ} \mathrm{F}\end{array}$ & $\mathrm{Ni}, \mathrm{Cr} . \mathrm{Fe} . \mathrm{Ti} . \mathrm{Mo}, \mathrm{O}$ & Ni. Cr. Si large Fe. O peaks & $\begin{array}{l}\text { Significant } \mathrm{Fe} / \mathrm{O} \text { transfer to journal. } \underline{\mathrm{No}} \\
\text { lubricants }(\mathrm{Ag} . \mathrm{Ca} . \mathrm{Ba}) \text { detected on journal }\end{array}$ \\
\hline $\begin{array}{l}427^{\circ} \mathrm{C} \\
800^{\circ} \mathrm{F} \\
\end{array}$ & $\mathrm{Ni}, \mathrm{Cr}, \mathrm{Fe}, \mathrm{Ti}, \mathrm{Mo}, \mathrm{O}$ & Ni, Cr,O, Ag, Ca. Ba, Fe, Si, Mo & $\begin{array}{l}\text { Detectable Fe/O transfer to journal. All } \\
\text { lubricants (Ag. Ca. Ba) detected on journal }\end{array}$ \\
\hline $\begin{array}{l}537^{\circ} \mathrm{C} \\
10000^{\circ} \mathrm{F}\end{array}$ & $\begin{array}{l}\text { Ni. Cr. Fe, Ti(Ba). Ca } \\
\text { Ag. Mo. O }\end{array}$ & Ni. Cr. O. Ag. Ca. Ba. Si. O & $\begin{array}{l}\text { Journal: increased } \mathrm{Cr} / \mathrm{Ni} \text { ratio, increased } \mathrm{Si} \text {. } \\
\text { O peak. All lubricants present. Foil surface: } \\
\text { exhibits significant Ag. Ca possibly } \mathrm{Ba} \text {. Si }\end{array}$ \\
\hline $\begin{array}{l}6.50{ }^{\circ} \mathrm{C} \\
12000^{\circ} \mathrm{F}\end{array}$ & $\begin{array}{l}\text { Ni. Cr, Fe. Ti(Ba). Ca } \\
\text { Ag. Mo. O }\end{array}$ & Ni. Cr, O, Ag, Ca, Ba, Mo, Fe, Si & $\begin{array}{l}\text { Journal: slight transfer of Fe. } \mathrm{M}(\mathrm{c}+(0) \text {. All } \\
\text { lubricants present foil surface: significant } \\
\text { lubricant (Ag. Ca. + Ba) transfer }\end{array}$ \\
\hline
\end{tabular}


TABLE III.-PIN-ON-DISK DATA SUMMARY FOR IX750 VERSUS PS304 AND PS300 COATINGS

[Data from reference 6.]

\begin{tabular}{|c|c|c|c|c|c|}
\hline $\begin{array}{c}\text { Disk } \\
\text { coating }\end{array}$ & $\begin{array}{c}\text { Pin } \\
\text { material }\end{array}$ & $\begin{array}{c}\text { Temperature. } \\
{ }^{\circ} \mathrm{C}\end{array}$ & $\begin{array}{c}\text { Friction } \\
\text { coefficient }\end{array}$ & Kpin. mm ${ }^{3} \mathrm{~N}-\mathrm{m}$ & Kdisk. mm $^{3} / \mathrm{N}-\mathrm{m}$ \\
\hline PS300 & INCX750 & 25 & $0.23 \pm 0.05$ & $3.9 \pm 0.5 \times 10^{-5}$ & $6.6 \pm 2.5 \times 10^{-5}$ \\
PS300 & INCX750 & 500 & $0.29 \pm 0.04$ & $1.3 \pm 0.3 \times 10^{-5}$ & $3.9 \pm 0.3 \times 10^{-4}$ \\
PS300 & INCX750 & 650 & $0.31 \pm 0.01$ & $3.1 \pm 0.8 \times 10^{-5}$ & $7.1 \pm 1.6 \times 10^{-4}$ \\
PS304 & INCX750 & 25 & $0.31 \pm 0.05$ & $0.96 \pm 0.3 \times 10^{-5}$ & $4.8 \pm 0.3 \times 10^{-4}$ \\
PS304 & INCX750 & 500 & $0.25 \pm 0.02$ & $0.32 \pm 0.5 \times 10^{-5}$ & $2.8 \pm 0.3 \times 10^{-4}$ \\
PS304 & INCX750 & 650 & $0.23 \pm 0.02$ & $0.38 \pm 0.4 \times 10^{-5}$ & $1.0 \pm 0.1 \times 10^{-4}$ \\
PS304 & INCX750) & 800 & $0.37 \pm 0.03$ & $6.9 \pm 2.0 \times 10^{5}$ & $2.6 \pm 0.2 \times 10^{4}$ \\
\hline
\end{tabular}

Note: Tests conducted in air, $4.9 \mathrm{n}$ load, $1 \mathrm{~m} / \mathrm{s}$ sliding elocity.

Specimen assembly end view

\section{Capacitance}

proximity probe

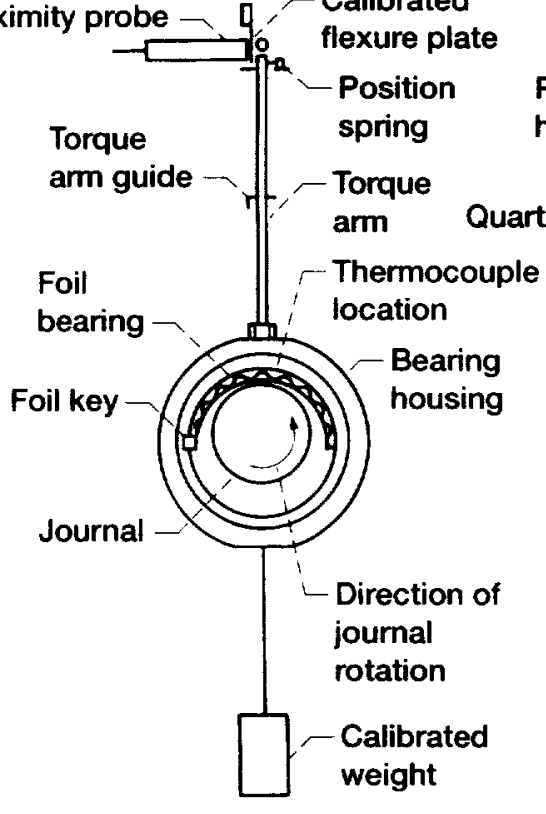

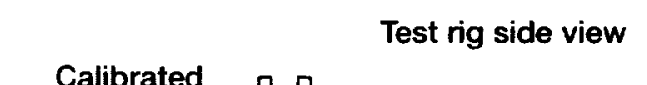

Calibrated

flexure

Removable
heat box $~$

lamp heaters

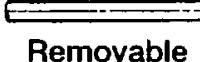

Removable

test

journal

Test

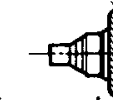

bearing and

floating

housing
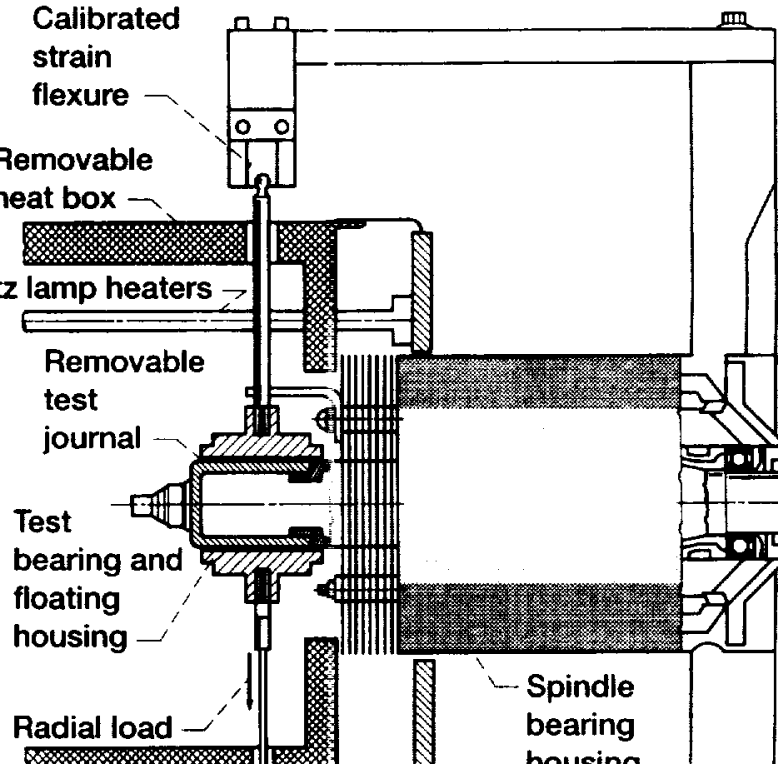

Fiber

optic rpm

probe

probe $\longrightarrow$

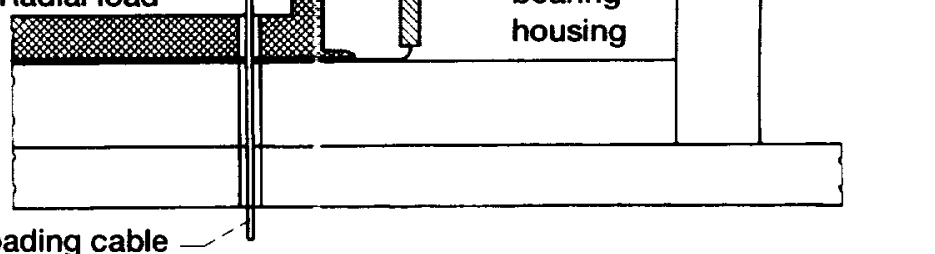

Deadweight loading cable

Figure 1.-Schematic view of test apparatus. 


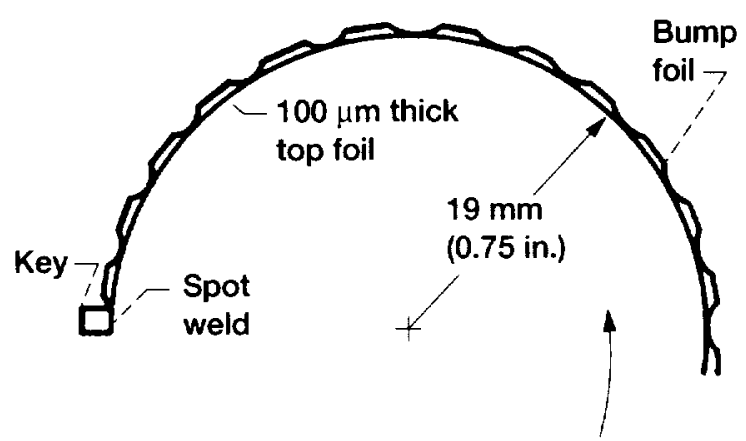

Rotation

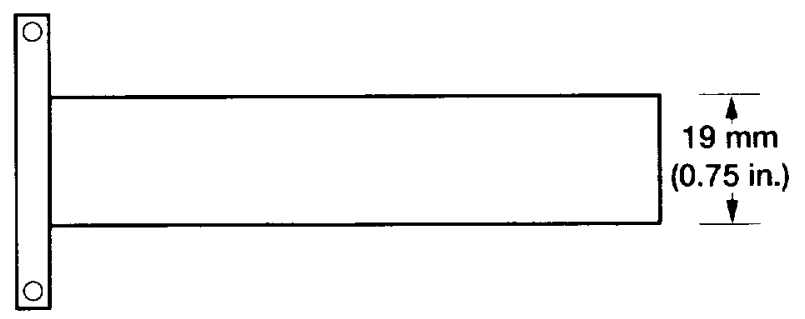

(a)

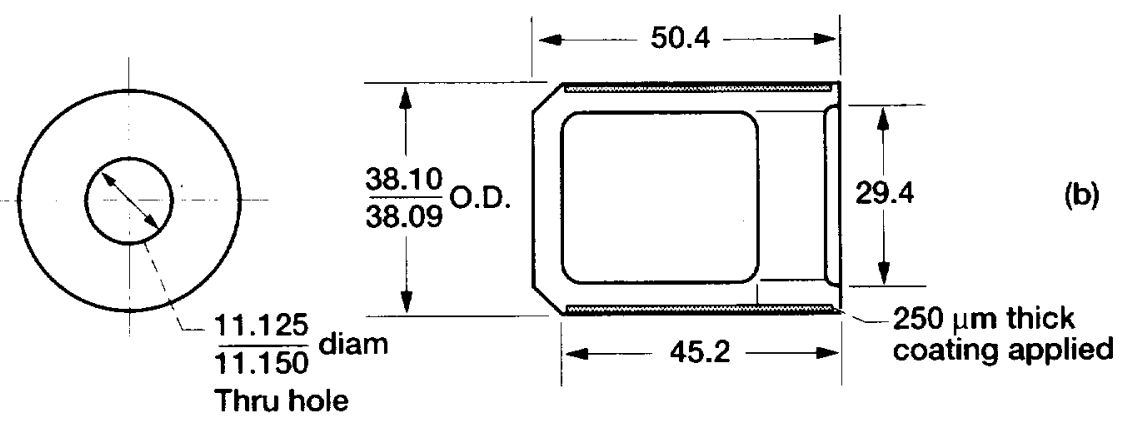

Figure 2.-Specimen geometry. (a) Foil. (b) Journal. Units in $\mathbf{m m}$. 


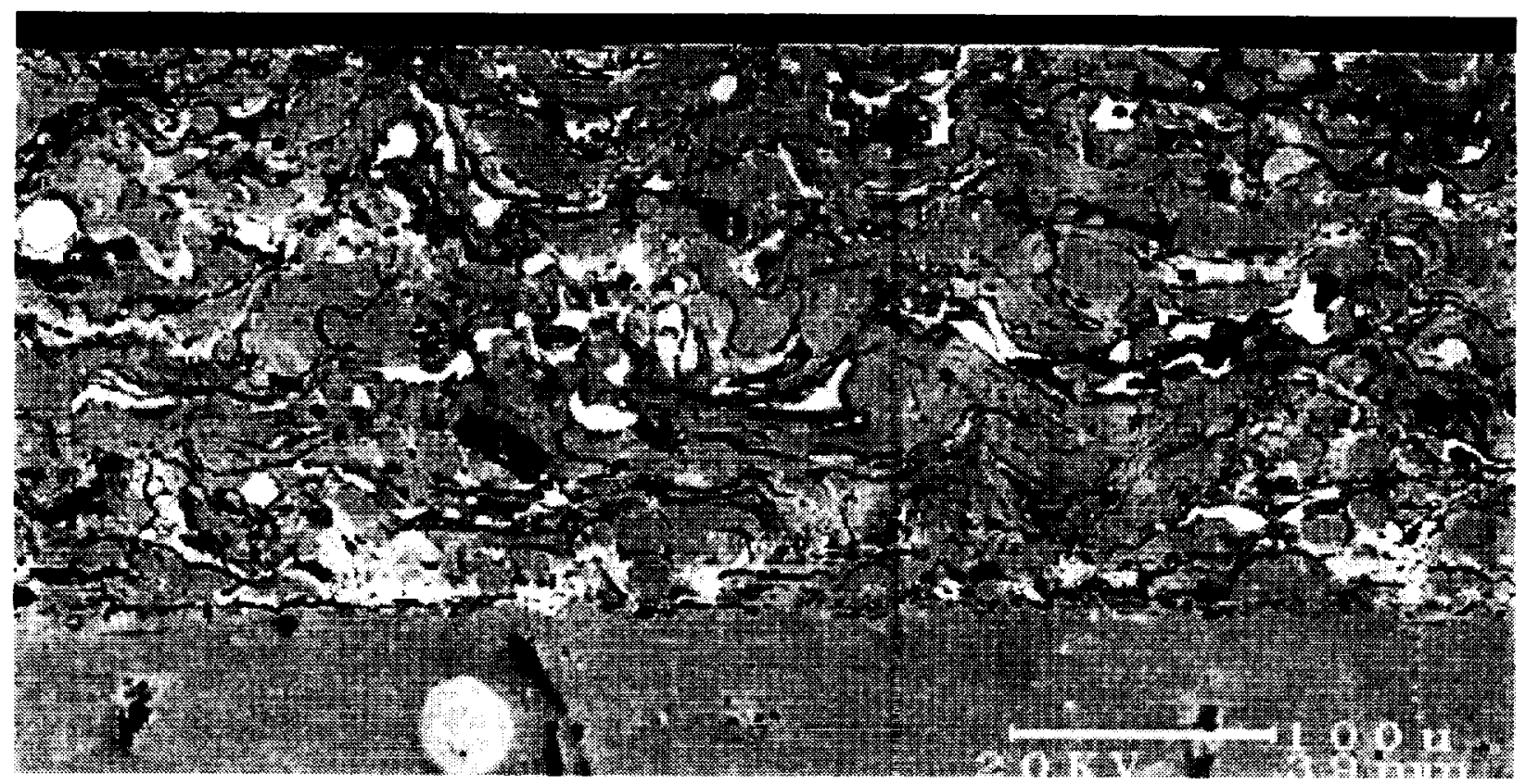

Figure 3.-Cross section SEM photomicrograph (backscattered) of PS 304.
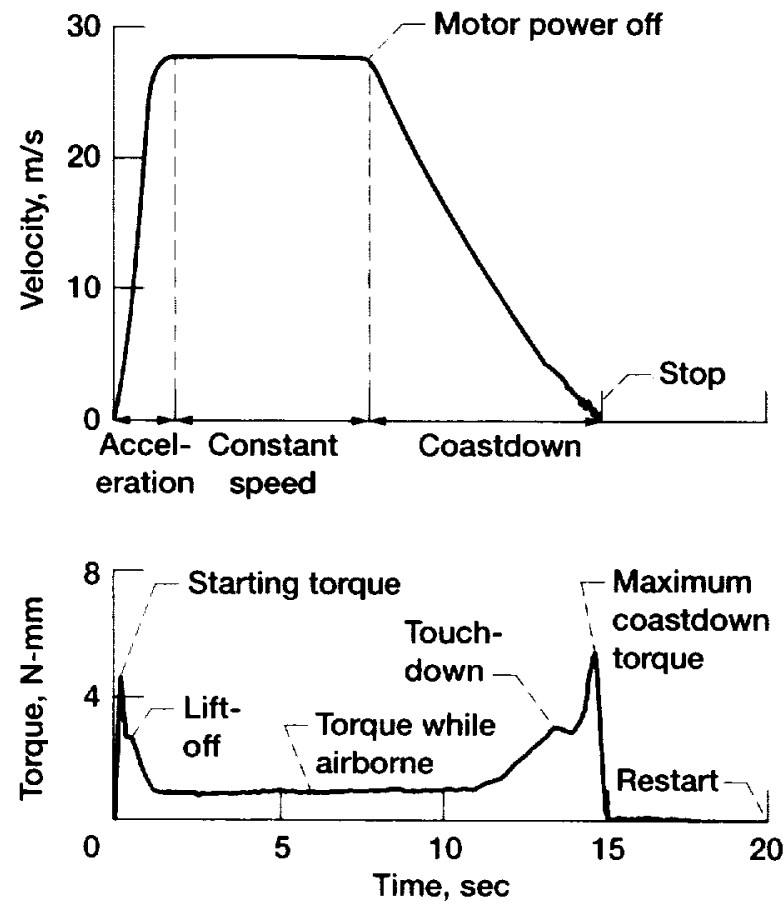

Figure 4.-Typical test cycle speed/torque trace.

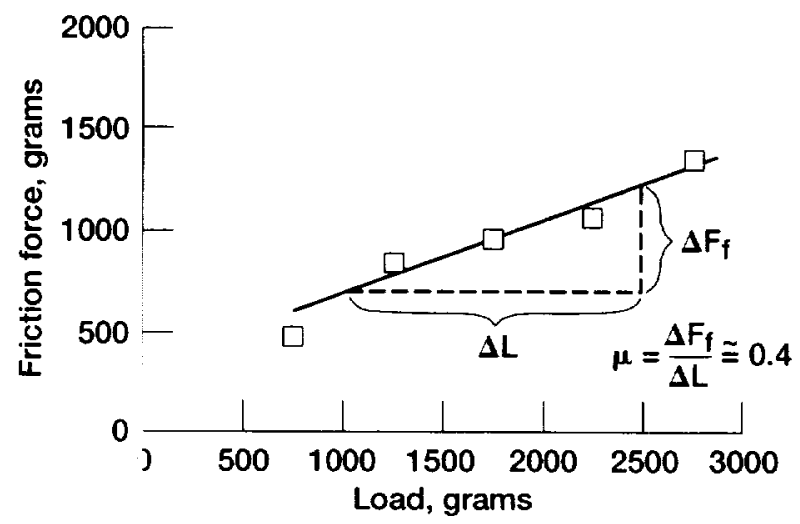

Figure 3 .-Example of friction force (bearing torque) versus load at $25^{\circ} \mathrm{C}\left(78^{\circ} \mathrm{F}\right)$ showing calculation of friction coefficient. 


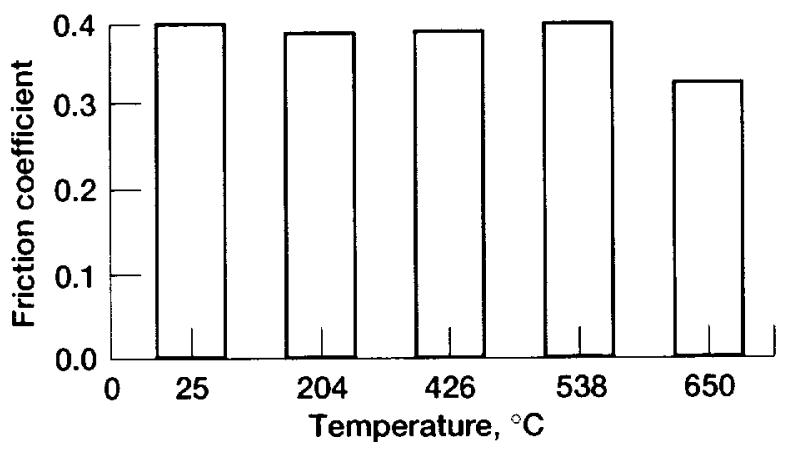

Figure 6.-Friction coefficient (calculated from apparent bearing torque) for PS 304 coated journals sliding against IX750 foil bearings.

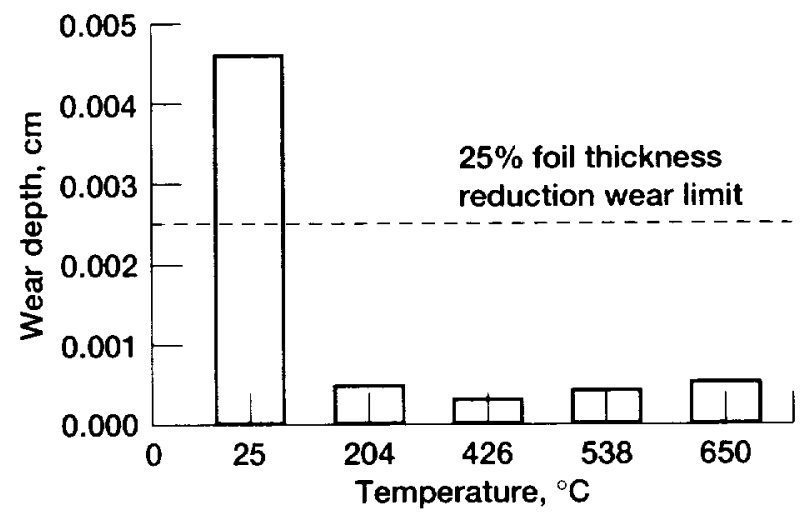

Figure 7.-Foil wear for IX750 foils slid against PS 304 coated journals under $10.4 \mathrm{kPa}$ load, 30,000 start/ stop cycles.

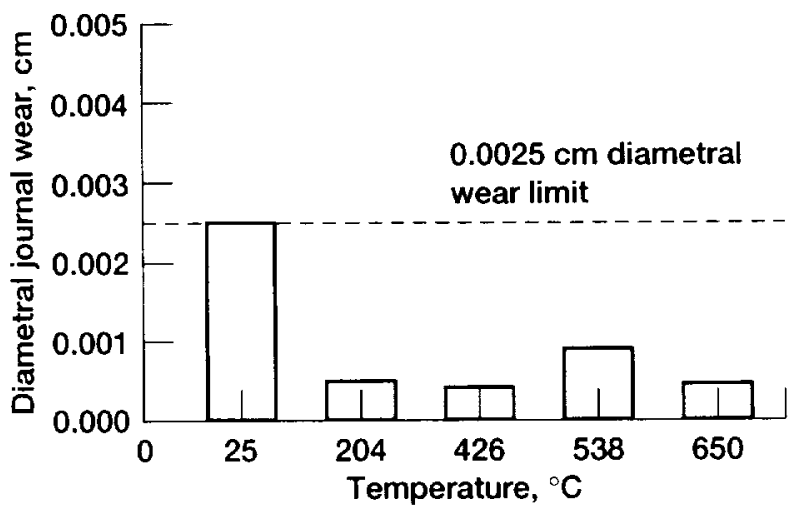

Figure 8.-Diametral journal wear of the PS 304 coating after sliding against IX750 foils under a $10.4 \mathrm{kPa}$ load, 30,000 start/stop cycles. 


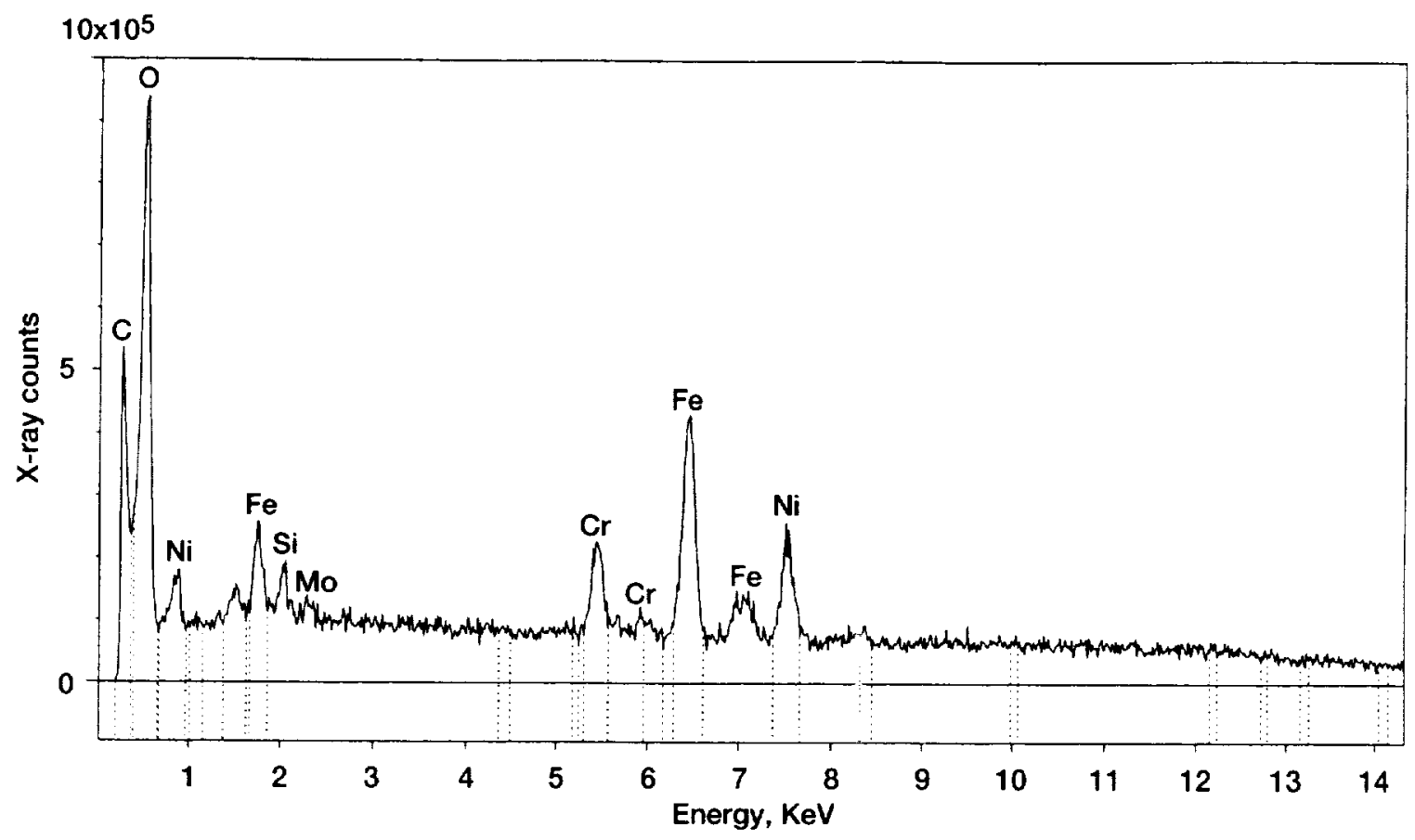

Figure 9.-EDS $x$-ray spectrum of PS 304 coated journal after sliding against foil at $204^{\circ} \mathrm{C}\left(400^{\circ} \mathrm{F}\right)$ for 30,000 start/stop cycles.

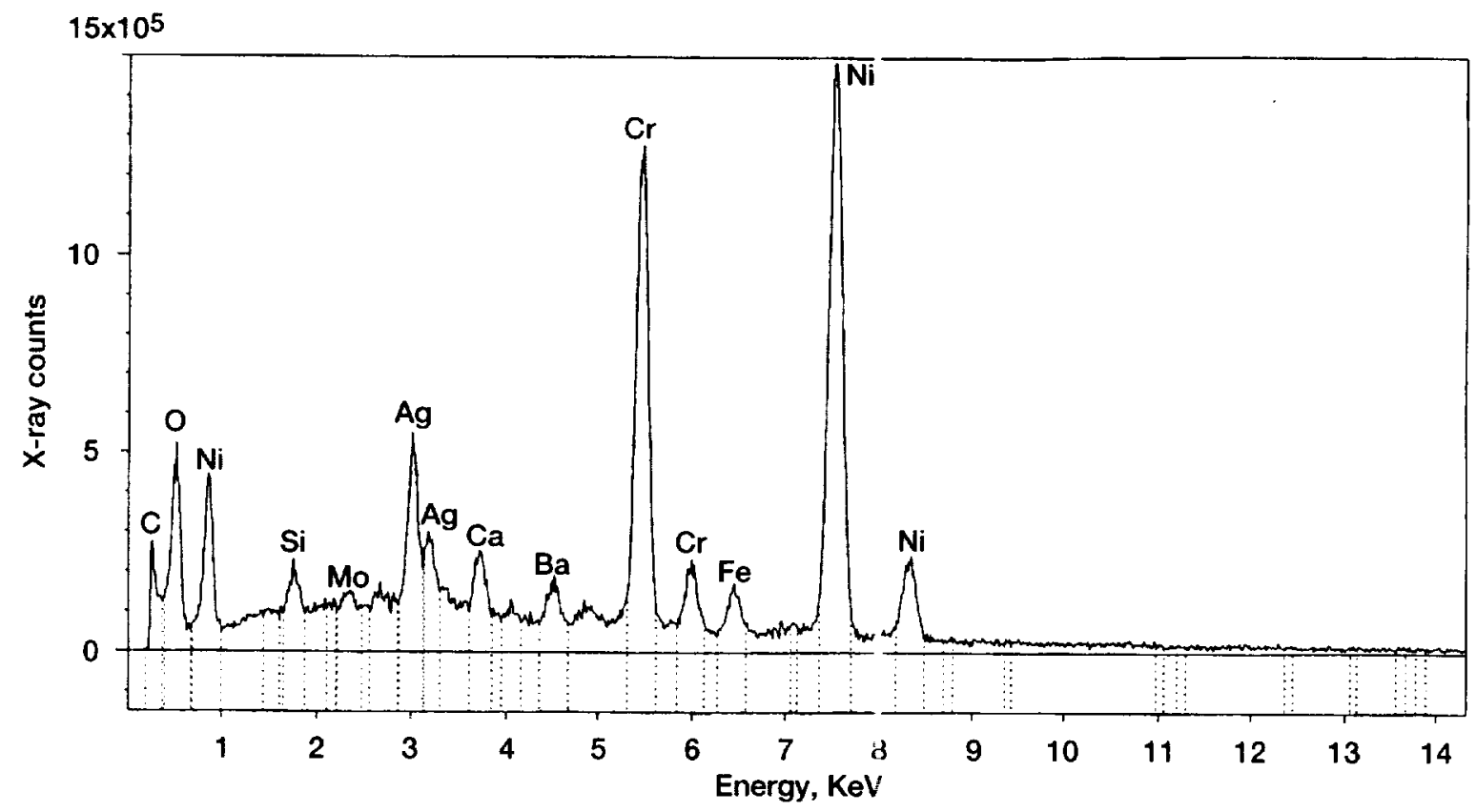

Figure 10.-EDS $x$-ray spectrum of PS 304 coated journal after sliding against foil at $427^{\circ} \mathrm{C}\left(800^{\circ} \mathrm{F}\right)$ for 30,000 start/stop cycles. 


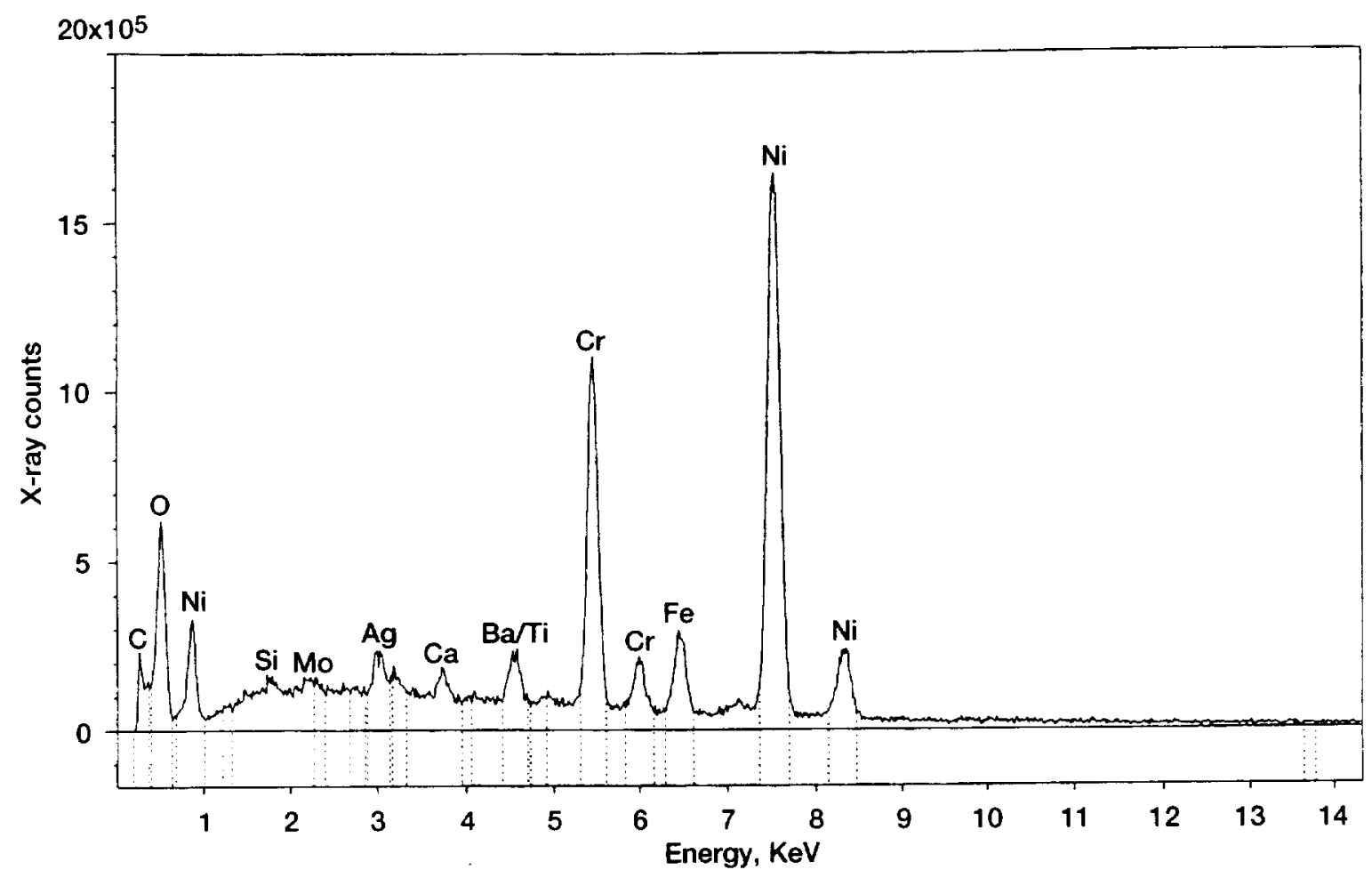

Figure 11.-EDS $x$-ray spectrum of foil surface after sliding against PS 304 coated journal at $538{ }^{\circ} \mathrm{C}$ $\left(1000^{\circ}\right.$ ) $)$ for 30,000 start/stop cycles. 
Public reporting burden for this collection of information is estimated to average 1 hour per response, inclu ting the time for reviewing instructions, searching existing data sources, gathering and maintaining the data needed. and completing and reviewing the collection of information. Stnd comments regarding this burden estimate or any other aspect of this collection of information, including suggestions for reducing this burden, to Washington Headquarters Servi :es. Directorate for Information Operations and Rep Davis Highway. Suite 1204. Arlington, VA 22202.4302, and to the Office of Management and Budgel. Paperwork Reduction Project (0704-0188). Washington, DC 20503.

\begin{tabular}{|l|l|l|}
\hline 1. AGENCY USE ONLY (Leave blank) & 2. REPORT DATE & 3. REPORT TYPE AND DATES COVERED
\end{tabular}

\begin{tabular}{|l|l|l|}
\hline October 1998 & Technical Memorandum \\
\hline
\end{tabular}

\section{TITLE AND SUBTITLE}

The Evaluation of a Modified Chrome Oxide Based High Temperature

Solid Lubricant Coating for Foil Gas Bearings

\section{AUTHOR(S)}

Chris DellaCorte

\section{PERFORMING ORGANIZATION NAME(S) AND ADDRESS(ES)}

National Aeronautics and Space Administration

Lewis Research Center

Cleveland, Ohio 44135-3191

\section{SPONSORING/MONITORING AGENCY NAME(S) AND ADDRESS(ES)}

National Aeronautics and Space Administration

Washington. DC 20546-0001
WU-523-22-13-00

8. PERFORMING ORGANIZATION REPORT NUMBER

$E-11361$

T. SPONSORINGMONITORING AGENCY REPORT NUMBER

NASA TM-1998-208660

\section{SUPPLEMENTARY NOTES}

Prepared for the Annual Meeting sponsored by the Society of Tribologists and Lubrication Engineers, Las Vegas, Nevada, May 23-27. 1999. Responsible person. Chris DellaCorte, organization code 5140, (216) 433-6056.

\section{2a. DISTRIBUTION/AVAILABILITY STATEMENT}

Unclassified - Unlimited

Subject Category: 23
Distribution: Nonstandard

This publication is available from the NASA Center for AcroSpace Information, (301) 621-0390.

\section{ABSTRACT (Maximum 200 words)}

This paper describes the friction and wear performance of PS304, a n odified chrome oxide based coating, for foil gas hearings. PS 304 contains $60 \mathrm{wt} \% \mathrm{NiCr}$ binder, $20 \mathrm{wt} \% \mathrm{Cr}_{2} \mathrm{O}_{3}$ hardentr, and $10 \mathrm{wt} \%$ each $\mathrm{Ag}$ and $\mathrm{BaF}_{2} / \mathrm{CaF}_{2}$ lubricants. For evaluation. the coating is plasma spray deposited onto test journa s which are slid against a superalloy partial arc foil hearing. The test load was $10 \mathrm{KPa}$ ( $1.5 \mathrm{psi}$ ) and the bearings were run under start/stop cyclic conditions. The data show good wear performance of the bearing especially at temperatures above $25^{\circ} \mathrm{C}$. Bearing friction was moderate $(\mu \cong 0.4)$ over the entire temperature range. Based upon the results obtained, the PS304 coating has promise for high temperature. oil-free turbomachinery applications.

\section{SUBJECT TERMS}

15. NUMBER OF PAGES

19

Solid lubricants; Gas foil bearings: High temperature

17. SECURITY CLASSIFICATION OF REPORT

Unclassified

18. SECURITY CLASSIFICATION
OF THIS PAGE
Unclassified

19. SECUAITY CLASSIFICATION OF AESTRACT Unclassified 